Int. J. Electrochem. Sci., 11 (2016) $4812-4827$

International Journal of

ELECTROCHEMICAL

SCIENCE

WWW.electrochemsci.org

\title{
Characterization of Strain-induced Martensite and Anodic Polarization Properties of a Newly Developed Lean Duplex Stainless Steel 2002 after Tensile Deformation
}

\author{
Yanjun Guo ${ }^{1}$, Jincheng $\mathrm{Hu}^{2}$, Yiming Jiang ${ }^{1}, \operatorname{Jin}_{\mathrm{Li}}{ }^{1, *}$ \\ ${ }^{1}$ Department of Materials Science, Fudan University, Shanghai 200433, China \\ ${ }^{2}$ Stainless Steel Branch, Baosteel Technology Center, Baosteel Co., LTD. Shanghai 200431, China \\ *E-mail: corrosion@ fudan.edu.cn
}

doi: $10.20964 / 2016.06 .36$

Received: 15 March 2016 / Accepted: 2 April 2016 / Published: 4 May 2016

\begin{abstract}
Strain-induced martensite in a newly developed lean duplex stainless steel (DSS) 2002 after tensile deformation was characterized by optical metallographic microscopy, scanning electron microscopy, transmission electron microscopy, X-ray diffraction and electron backscatter diffraction techniques. Magnetic property measurement and HV hardness test of specimens with different strains were performed. The polarization curves of DSS 2002 after tensile deformation in $3.5 \mathrm{wt} \% \mathrm{NaCl}(\mathrm{pH} \approx 7)$ and $3.5 \mathrm{wt} . \% \mathrm{NaCl}+0.01 \mathrm{~mol} / \mathrm{L} \mathrm{HCl}(\mathrm{pH} \approx 2)$ were measured. The results showed that as the tensile deformation increased from 0 to $40 \%$, the volume fraction of strain-induced martensite, the magnetization saturation and the micro-hardness values increased. The pitting potential of DSS 2002 in $3.5 \mathrm{wt} . \% \mathrm{NaCl}$ solution was not greatly influenced by deformation but the critical passivation current density of specimens increased with increasing deformation. While, the pitting potential of DSS 2002 in $3.5 \mathrm{wt} . \% \mathrm{NaCl}+0.01 \mathrm{~mol} / \mathrm{L} \mathrm{HCl}$ decreased with the increase of tensile deformation. The effect of tensile deformation on anodic polarization properties of DSS 2002 in chloride solutions of different $\mathrm{pH}$ was discussed.
\end{abstract}

Keywords: duplex stainless steel; tensile deformation; strain-induced martensite; anodic polarization properties

\section{FULL TEXT}

(C) 2016 The Authors. Published by ESG (www.electrochemsci.org). This article is an open access article distributed under the terms and conditions of the Creative Commons Attribution license (http://creativecommons.org/licenses/by/4.0/). 